\title{
Pursuit of the Red Passport: Perceptions of Global Citizenship Among Low-paid Global Workers
}

\author{
Whitney Haynes \\ University of Oslo \\ whaynes@ualberta.ca
}

\begin{abstract}
The movement of people around the world for the sole purpose of their labour has existed for hundreds of years and is at the root of a growing capitalist regime. Today, millions of people, particularly from low-income countries, are forced to move without their families across borders to high-income countries in order to send home remittances to help their families survive. The control of their global movement is based on a system of borders and visa regulations, where their passports, determined by their citizenship, offer very limited global mobility. This article explores the current context of low-paid labour migration in relation to global citizenship and global mobility rights. Workers interviewed in Canada, parts of Europe and Asia $(n=24)$ describe their quests for the freedom of global mobility and navigating citizenship systems in order to obtain a strong passport/citizenship, also known as the "red passport." The fight for the red passport and the right to global mobility is linked to their understandings of true global citizenship.
\end{abstract}

\section{Introduction}

This is not a new story. It has been going on for thousands of years. Migration and abuse is an interlinked process. There are jobs we want to do, and then there are jobs we don't want to do. So, we import the workers. It has been called slavery, then bonded labour, now it is called labour movement. But the migration story is repeated generation after generation with different rationalization for the ongoing abuse. The face changes but the story does not.

Community Organizer, Kenya ${ }^{1}$, Canada ${ }^{2}$ (semi-structured interview, December, 2013)

The movement of people around the world in the 21 st century is defined by borders and visas. To cross between nation-states, individuals require a travel document, such as a passport issued from their country of origin that provides proof of their citizenship. Receiving countries then grant visas based on the strength of an individual passport. Entry into a country is allowed whereby citizens of high-income, "developed" nations are more likely to be accepted (i.e., have greater power of access) and are insulated by political bodies that maintain the greatest control of international borders either through direct or indirect influence. Passports or citizenships today are sought after for this power. Arton Capital, a corporation in Canada, ranks passports/citizenships based on their "visa-free score" or in more specific terms, the level of global mobility the passport affords. Arton Capital is identified by their trademark "empowering

${ }^{1}$ Country of origin

${ }^{2}$ Current country

Journal of Contemporary Issues in Education, 2017, 12(1), pp. 4-18.

ISSN 1718-4770 @ 2017 University of Alberta/Centre for Global Citizenship Education and Research http://ejournals.library.ualberta.ca/index.php/JCIE 
global citizenship;" citizenship is defined by the right to global mobility, and this right must be purchased.

"Global mobility rights" can be considered rights of freedom to move globally but as yet, these are not formally recognized as basic human rights. Citizenship is the foundation for the rights one is/should be entitled to within their own country, including the right to freely move within the boundaries of their nation-state without permission. Global citizenship does not extend the protection of human rights globally or the access to move globally. It is a metaphor of global belonging within the educational sphere (Tawil, 2013). However, discussions of what it means to belong globally across borders must examine who can cross one border, or many borders, and who cannot.

The underlying oppressive structures of international borders subjugate groups of people into levels of global mobility rights. Individuals born without or with lower global mobility rights (generally low and middle-income groups of low-income countries) are often immobile, compared to individuals born with global mobility rights (most high-income nationals) or individuals able to purchase global mobility rights (elites, or the upper class of all countries).

This international system serves as an impetus for the temporary movement of cheap labour from low-income countries to high-income countries where workers rarely have the freedom to leave. This system takes advantage of and controls citizens from poor backgrounds and without mobility rights as they remain otherwise immobile under their own passport/citizenship. Without global mobility rights, workers are under the control of the companies and countries that employ them. However, controlling people for labour across borders is not a new phenomenon. Slaves, bonded labourers, guest workers, migrant workers, and temporary foreign workers are labels that have been and are used to describe individuals displaced and commodified for the economic benefit of others - other people and other nations.

Today's temporary transport of people from low-income countries to high-income countries, for the sole purpose of cheap labour, is based on an evolving system of labour control and power. The transient nature of the current low-paid global labour population is imbued with longstanding hegemony in which rich countries have historically maintained power through the exploitation of other lands and other people. Labour migration which is founded on capitalist and imperialist activities is driven by power and control. For hundreds of years, capitalism and imperialism have interacted to provide a setting in which millions of workers have been scattered across the world and reduced to being a supply of "living labor power" (Potts, 1990, p. 2). This world market for living labour power includes the transfer of human beings to various geographical locations in order to perform labour that locals prefer not to do. Tracing the enslavement of indigenous people during European conquests of the Americas, Africa, and Asia, Potts outlines how people from every inhabited continent have been pushed into the world market through forced labour practices and colonialism. The stark differences of the colonized and colonizing populations continue to be tied to the agenda of a growing global market: "for the original inhabitants of America and Australia and the residents of Asia and Africa, this has meant extermination, abduction, and exploitation. For at least part of the white people's [Eurocentric] world it has meant material wealth" (p. 7).

Journal of Contemporary Issues in Education, 2017, 12(1), pp. 4-18. ISSN 1718-4770 (C) 2017 University of Alberta/Centre for Global Citizenship Education and Research http:/lejournals.library.ualberta.ca/index.php/JCIE 
Today, cheap labour (or people) from impoverished communities are lured into a dream of finally being able to support their families within the global economy while living and working thousands of miles away. This opportunity offered by some countries is just temporary: a gift from the economies of the rich to help people unable to help themselves. Canada is only one example. Canadian temporary foreign workers are granted one to four years of entry to work difficult jobs that pay minimum wage from which workers can try to save as much money as possible. During this time, Canada offers them another gift: the prospect of becoming Canadian, which includes not only membership into a rich economy but a passport granting global mobility rights.

However, many of these workers' efforts are futile, and they are often unable to move beyond being a cheap source of labour. The opportunity of Canadian citizenship only exists for individuals who pass language proficiency exams, complete a certain number of years of work experience and offer desirable high skills (Citizenship and Immigration Canada, 2016). After spending thousands of dollars on applications to enter Canada and on trying to establish a sense of belonging to Canada, workers are typically flown back home to be replaced by another batch of cheap labour. Aziz Choudry and Adrian Smith (2016) equate this management of border controls "to a rotating-door labour market geared to just-in-time production or services" (p. 3).

Objectification and dehumanization of people from low-income countries as internationallysourced cheap labour becomes clear when looking at the number of countries that have signed the United Nations International Convention on the Protection of the Rights of All Migrant Workers and Members of Their Families. Of all the United Nations' human rights treaties, it has been the least ratified, with only 49 countries' acknowledgment since 1990 (Ruhs, 2013). Not one of these 49 countries would be considered a rich economy. Considering these few signatories, Martin Ruhs (2012) concludes that "the world's high-income countries - where migrants are most heavily concentrated - clearly do not accept that these rights should also apply to migrants living on their territories" (p. 1282). Ruhs discusses how there has been a lack of promotion, awareness and understanding of this treaty. He also explains that many countries use the argument of the immense number of legal issues that this treaty would create, if enforced. However, behind this argument seems to be the "equally important, if not decisive obstacle" (p. 1284) outlining the real costs of implementing the treaty, which is based on the price of granting people their humanity.

This article will examine the meaning of global citizenship, or global belonging, within the context of current labour movement patterns. This understanding of global citizenship was explored in a qualitative research study interviewing low-paid global workers working in different high-income countries. Their experiences and perceptions of global belonging across borders contribute significantly to understanding and exploring outside-the-classroom global citizenship realities today.

First, as history sets the foundation for current power dynamics between nation-states, a framework will be established by examining the history of labour migration in terms of forced mobility and immobility, countries currently in power, and the influence of these countries in the displacement and movement of people around the world for temporary work. Following this, stories and knowledge from low-paid global workers and community actors working or volunteering in the field of labour migration will be shared. The article will focus on exploring

Journal of Contemporary Issues in Education, 2017, 12(1), pp. 4-18. ISSN 1718-4770 (C) 2017 University of Alberta/Centre for Global Citizenship Education and Research http://ejournals.library.ualberta.ca/index.php/JCIE 
the ideal of global citizenship within the context of forced and limited global mobility labour patterns from low-income to high-income nation-states.

\section{The Immobility and Forced Mobility of Global Labour: A Historical Context}

Slavery or unfree labour has existed for centuries in many pockets throughout the world: from the Arab-run slave trade in East Africa, Arabia and the Indian Ocean to slavery under the Roman Empire. More recently, from the $17^{\text {th }}$ to the middle of the $19^{\text {th }}$ century, there was forced movement of Africans to work as slaves in North America for almost 250 years (Carey, 2016). In the 1830s, the British Empire abolished slavery in their territories, yet also expanded their Indian indentured immigration system, which resulted in over 1.9 million Indians relocating to 19 colonies over the course of 100 years as a new and transformed system of cheap labour. Fiji, Guyana, Suriname as well as Trinidad and Tobago have archived their records during this time, which have now been preserved in The Memory of the World Register developed under the United Nations Educational, Scientific and Cultural Organization (UNESCO). Their report describes this level of labour movement as: "hasty and unorthodox targeting the populous of poverty stricken Indian provinces some landless and affected by food shortages and unemployment due in part to the commercialization of the Indian economy generated by British economic policies" (Fiji, Guyana, Suriname, Trinidad and Tobago, 2010, p. 1). A community organizer in Canada, Madhu, who is originally from Kenya describes her and her family's journey across continents:

My grandfather was a bonded labourer, was brought over [from India] by the British to build railways. He lost the sight of one eye and the sight of half of the other eye. He wasn't allowed to leave until he substituted a bonded labourer, which was my father at the age of 16.

Potts (1990) explains that shifting from slavery to bonded labour was more profitable since bonded slaves replaced themselves if they could no longer work, whereas if an African slave died, was unfit for work, or ran away, new slaves had to be purchased. This transformation of slavery into a new organization of cheap labour movement from the $19^{\text {th }}$ and $20^{\text {th }}$ centuries has been reinvented yet again late in the $20^{\text {th }}$ century and now in the $21^{\text {st }}$ century with a very similar story and, of course, a new title.

The transformed term used to describe workers brought into Europe in the second half of the $20^{\text {th }}$ century was "guest workers." Potts (1990) explains how the level of dehumanization worked at the time:

the scale, structure and course of labour migration has been controlled unequivocally and exclusively by the countries that play host to migrant workers. It is they who determine the composition of the waves of migration in terms of qualifications, age, marital status, and gender. The scale and timing of arrivals and departures and the pattern of immigration and remigration are directly dependent on the economic climate and the state of the labour market in host countries... (p. 208)

Potts specifies how Germany and Switzerland made profits by selectively sending guest workers home in times of economic crisis. The International Labour Organization (ILO) in the $21^{\text {st }}$ century reflected on the difference between welcoming workers versus people across borders at 
this time, through quoting Swiss writer Max Frisch: "We invited guest workers, and got human beings" (ILO, 2004, p. 111). This temporary use of people, reduced just to the work that they perform and thrown away when no longer profitable, has become more complex and organized today.

\section{Connecting With Low-paid Global Workers}

The individual stories presented in this article are based on semi-structured interviews, focus groups and observations conducted both among individuals working in low-paid jobs without permanent residency or citizenship status $(n=24)$ in high income economies as well as community actors $(n=8)$ engaged in labour migration issues.

Workers interviewed were primarily from Nepal, the Philippines, Pakistan, and India. Stories were shared by both women and men working in parts of Europe and Canada and men working in the Gulf States and East Asia. Interviews, focus groups and observations took place in Edmonton (Canada), Oslo (Norway), Lisbon (Portugal) and Kathmandu (Nepal) from September 2014 to February 2015. Within each region, North America, Europe, and Asia ${ }^{3}$, between eight to ten reflections from workers were recorded (digitally or by hand), with some workers sharing experiences in more than one region. Overall, migration systems across these regions "welcome" low-paid migrant workers in distinct ways. This exploratory study examined these differences by looking at the experiences and perspectives of workers learning/fighting to belong and understand their rights within and while crossing these borders.

I decided that the most comfortable way for participants to trust me, a white Canadian female, and feel safe sharing their stories and opinions, was for me to be introduced to them through a community member that they themselves trusted. I was able to access Nepalese communities because of the years that I had lived in Nepal and my Nepalese connections in Europe. This enabled me to live within the Nepalese community in Lisbon, Portugal during field work and connect to Nepalese workers in Norway. For safety reasons, I did not feel comfortable interviewing workers in receiving countries in the Asia region. Therefore, I chose to base myself in a migrant sending country, Nepal, during their major holiday season when workers come home from working abroad, particularly from Gulf States and East Asia. As Edmonton, Canada is my home, my connections to the community there are stronger, making it easier to connect to different community members that could link me to low-paid migrant workers, who then linked me to other low-paid migrant workers.

I personally transcribed all interviews and typed all field notes in order to immerse myself and constantly compare all the data using both inductive and deductive methods. The one major inductive theme that emerged was the freedom of global mobility. All names of individuals have been made anonymous unless a participant explicitly requested their name to be used.

Throughout the research field work, I continually faced and reflected on the power dynamics present as a white female researcher from a western country with a Canadian passport. A statement I still continually play over in my mind was from a worker in Lisbon, Portugal who

\footnotetext{
${ }^{3}$ Areas in Canada covered include: Alberta and Quebec; Countries in Europe include: Austria, England, Germany, Norway, Portugal, and Sweden; Countries in the Gulf and East and Southeast Asia include: Saudi Arabia, South Korea, Taiwan and the United Arab Emirates.
}

Journal of Contemporary Issues in Education, 2017, 12(1), pp. 4-18. ISSN 1718-4770 (C) 2017 University of Alberta/Centre for Global Citizenship Education and Research http:/lejournals.library.ualberta.ca/index.php/JCIE 
sternly stated: "You will never understand; you have a Canadian passport." The freedom I have to be a global citizen (defined here as the capacity to travel and live globally without question) is a privilege I took with me to each interview, where I listened to the struggles of participants to get a different passport in order to gain the same freedom for themselves and their children.

The freedom of easily crossing borders was further underlined when I was travelling back to Europe from Kathmandu. I was travelling with my Nepalese translator and another Nepalese woman. At every airport checkpoint along the way to Oslo (passing through Mumbai to Paris, then Paris to Oslo), my two Nepalese travel companions were stopped and double checked. Finally, while boarding our final plane, they were pulled aside yet again, just to be sure that they could cross into Europe, while I waited on the side with white skin and my Canadian (or global) passport.

\section{Today’s Repackaged System of Cheap Labour Movement}

In the $21^{\text {st }}$ century, people reduced to cheap labour are described as migrant workers or temporary foreign workers. Millions of people from low-income countries traverse the globe to work in rich nations in order to support their families back home with the hope of a better future. Remittances sent back to countries of origin total half a trillion dollars a year (MDCSN, 2014). This significant amount of capital centers on workers transferring parts of their salaries from each paycheck, from higher wage labour markets (or high-income countries) to their families and members of their community, living in lower wage labour markets (or low-income countries). Families are separated by border controls imposed by rich nations, which often only allow a worker to enter. The precarious work performed is often for a lower wage than a local would have received for the same employment. In many rich nations, such as Canada, Norway, the United Kingdom and South Korea, workers are bonded to their employers (Faraday, 2012; Levush, 2013). Their working visa grants them permission to enter the rich nation but does not allow them to work for anyone other than the employer listed. Frequently, the humane excuse given for this trading of people is rich nations helping people in poor nations out of poverty. This "rational" reasoning ignores historic and current power dynamics that have led to certain nations becoming rich at the expense of others.

The control of the World Bank and the International Monetary Fund by high-income countries, for example, has resulted in the imposition of financial rules and systems onto low-income countries over the past 50 years. Structural adjustment programs in the 1980s forced low-income countries to remove trade and investment barriers, pressured cuts to public services, and forced the privatization of systems and communal land. Debt repayments compounded by incredibly high interest rates not only added to the oppressed position of low-income countries today, but the policies that removed trade and investment barriers became a "passport" for multinational corporations, most of which originate in high-income countries, to access the economic and natural resources of these nations. This "passport" to the economies of "developing" countries results in, not only the dispossession of billions of people of their resources, but also the displacement of communities, whether it be through environmental repercussions or the stimulation of conflict. ${ }^{4}$

\footnotetext{
${ }^{4}$ See for instance, trade and commodity market instability and mining effects across Africa discussed in Bush, 2008, mining induced conflict in the Philippines (Holden, Nadeau, \& Jacobson, 2011), mining and dispossession in Latin
}

Journal of Contemporary Issues in Education, 2017, 12(1), pp. 4-18. ISSN 1718-4770 (C) 2017 University of Alberta/Centre for Global Citizenship Education and Research http://ejournals.library.ualberta.ca/index.php/JCIE 
Further, the patronization of the rich giving an opportunity for poor people in poor countries to help themselves out of poverty by offering them difficult low-paying jobs across oceans, away from their families, not only ignores the history of why these countries are poor, it also obscures the enormous profits made today by governments and corporations through the system of labour movement. A community organizer, Marco, originally from the Philippines, but now working in Canada critically questions the opportunity given to low-paid global workers in high-income countries:

It is a billion dollar industry, migration. It is not going to stop. And that is why I am really critical of people just talking just about the temporary foreign worker program. I am really critical of people talking about jobs here for temporaries, a temporary foreign worker program with a human face, because it is a business, it is a global, billion dollar business that really has to be exposed.

The Philippines government has jumped onto this opportunity of trading people for labour across borders by advertising its own people:

Not only am I the head of state responsible for a nation of 80 million people. I'm also the CEO of a global Philippine enterprise of 8 million Filipinos who live and work abroad and generate billions of dollars a year in revenue for our country.

President Gloria Macapagal-Arroyo, May 2003 (Rodriguez, 2010, p. ix)

The Philippines is a central example of a labour brokerage state. Robin Rodriguez (2013) discusses the business of rich countries/economies negotiating with the Philippines government to formalize the flows of Filipinos as migrant workers in her book: Migrants for export: How the Philippine State brokers labour to the world. The settlements made between countries often include the expectation that workers return to their homeland (the Philippines) at the conclusion of their employment contracts, often to be replaced by another worker.

An international non-governmental organization representative, Daniel, stationed in Nepal and working in the area of migrant worker rights in the Gulf and Asia region, also explains the large stakes governments have in the labour migration business:

There is always a big clash between NGOs on the one hand and the ministry on the other hand, who are very well connected politically and who have a lot at stake because of big business. So, they do not want more responsibilities on them to look after the welfare of the workers [abroad].

In order to protect their connections with and profits from big business, governments have also taken control of global discussions on the topic of labour migration. Daniel further explains how discussions have moved away from the offices of the United Nations:

There was a commission once in 2005, which was a global commission on international migration, and Kofi Annan said we have to look at international

American (Gordon \& Webber, 2008) and an overview of mining in 'developing countries' (Bebbington, Hinojosa, Bebbington, Burneo, \& Warnaars, 2008). 
migration. They put a few experts together and they wrote a few very good papers and then this thing was hijacked a year later when governments said this is very interesting but we do not like this to be under the offices of the UN. We would like this to be a government led process because we have a stake in this and so on. So since then it has been a rotating event every couple of years that gets hosted by different governments. And over the years, our partners have been trying, together with other networks of migrants and NGOs, to organize parallel events and to be part of the official events also that go on to say look, it is all very well for governments to sit together and talk about this, but you often do not look at the concerns of migrants and migrants' rights and especially those migrants who we are speaking for, who are working at these lower skilled jobs.

The business of shifting people across borders for work is highly controlled, from governments such as the Philippines advertising their people as workers, to all migrant receiving countries monopolizing global discussions specific to labour migration. Outside the business deals is the equally profitable administration of managing cheap labour globally. Marco, a community organizer in Canada, who is originally from the Philippines, discusses this method of generating income for governments:

The government not only makes money from remittances, which is approximately 22 billion per year...But even institutions in the Philippines are created in order to send people abroad. This institution also collects money in order for migrants to leave. So, from a recruiter in Barrio to the actual agencies in Manila, they all made money from one migrant worker. A migrant worker's documents need to have approximately 98 signatures. 100 pesos [approximately 2 US dollars] per signature, in order for them to get that document to be able to leave. That is excluding the processing fee that the recruiter gets and the travel agencies. Imagine that, meanwhile when they get to Canada, recruiters also get them, and they need to pay these recruiters up to 10,000 dollars [approximately 7,500 US dollars], here in Canada.

Different countries find different ways to take advantage of the weak passports of migrant workers and charge fees to process the legal paperwork involved to move a worker from country A to country B. Jason, originally from the Philippines, discusses his costs in Taiwan in order to apply to enter Canada for work:

We must spend money also. Taiwanese can go to Canada immediately with passport. They do not need a visa. But we need a visa. 6,000 Canadian [approximately 4,500 US dollars] to agency without a plane ticket. I applied as a kitchen helper. Spent lots of money, but the Canadian government does not know we pay the agency. Our employer does not know either because there are rules in Taiwan. Canadian law is just the plane ticket and processing fee. But Taiwan takes lots of money. Unfair also because when we land here we are just a low wage worker. That money you have to get back when you work here. (Jason, Philippines, worker-Canada) 
Borders, visas, paperwork processing fees and other costs, all controlled by people profiting from labour migration, can render workers immobile. Min, originally from Nepal, explains his difficulty in receiving an already approved three month vacation while working in Saudi Arabia, to go home and be with his family:

They tell me three months vacation, but they were cheating me. They just gave two months. Then after I asked with my supervisor. He already gave permission to me three months vacation. Why you give me only two months? Then he said we extend your visa one month. Then I went to manpower to get the visa extended for one month. So it is costly really. He tells me it is around 17,000 [NPR approximately 155 US dollars]. And at that time I requested with my supervisor, it is 17,000 rupees, you have to pay or not? If you didn't pay, I cannot come there. He was telling me, this is your problem, you have to pay.

This exploitation of people in desperate situations mimics that of the Indian indentured labourers struggling in poverty and easily lured across oceans and deceived about the work on offer. Madhu, born in Kenya and now a community organizer in Canada, describes the repackaging of forced labour migration today in comparison to her father and grandfather's time:

The one thing at that time that was done for the bonded labourers, as another word for slave, ethically is to say that these bonded labourers had the British nationality. What has shifted in the last 50-60 years as migration has become a much wider spectrum, as corporations have consolidated more and more power, is that now we do not really value those labourers in permanence. Labour has really become a temporary solution for this moment in time: the very basis of consumerism. You eat or you buy what you like. You don't like it, you throw it away; if it stops working you throw it away; if it gets hurt you throw it away, because there is always a new mass that you can go and buy.

The foundation of today's dehumanized system of cheap labour movement is based on a worker being temporary, of not belonging, while situated at the bottom of a system of citizenship/passport hierarchies and border controls. The way out of the cycle of being an objectified piece of cheap labour shuttled from country to country is to join the people in power - the red passport holders.

\section{The Red Passport Is Global Citizenship}

The desire for the security of permanent belonging (on paper) to a high-income economy as well as full global mobility rights, can be achieved by upgrading one's citizenship and, therefore, one's passport. For many low-paid global workers in Europe, the term used to describe this upgrade is the red passport. This is because all European Union (EU) passports are red in color. However, throughout my fieldwork, passports of high-income countries that are not part of the EU were also assumed to be red. This term seems to extend beyond Europe as a metaphor of a 
strong passport or citizenship that can grant one the freedom of global mobility, that is, true global citizenship.

The drive for the freedom of global mobility, to join the red passport holders is repeated over and over again by the workers in this study. Min's story began in Nepal, in his home village where he grew up unable to find work. He then migrated to Saudi Arabia for work to support his family. A few years later, an opportunity arose to cross the Swedish border and work there. He was not allowed to bring his family; nor, was he given the chance to apply for citizenship in either country. When his visa for Sweden was coming to an end, he decided to migrate to Portugal. He explained why he stayed there:

My children are telling you and me, if my parents get us in the Europe and we get the European nationality and citizenship, then after better life. They have options. For reading [studies], they can go anywhere. If they didn't do, they have only one option. If they have European nationality, that means they can stay anywhere. They can spend a better life. That is the reason she [his wife] is telling me: "you must return back to Portugal." That is why I am here.

Portugal allows workers to apply for temporary residency and then permanent residency as long as they have an employment contract, are up to date with payments to the registered social security system and meet health, safety and security standards. A worker with a valid residence permit, no matter their perceived skills, may sponsor their family to join them as long as they prove they have accommodation and means of subsistence (Serviço de Estrangeiros e Fronteiras, 2012). Min explained why obtaining the red passport in Portugal finally led to his and his family's dignity:

When I was in Saudi for the labour visa we were not like a local. No one can feel like a local in the Middle East I think. In Sweden I also feel like that because I cannot stay a long time because the Swedish government cannot provide for me for a long time, if I stay there. I feel a little bit better for Portugal, because Portuguese legalize for us and we are gathering the family and the children too...Anywhere else I cannot success in gathering the family, but here I am success. Not everywhere, but here.

After years of supporting his family across borders, not only is Min now able to work and live in the same country as his family, he also navigated the system to obtain the freedom of global mobility for his wife and children. One of Min's goals was to give his children the option of studying globally in order for them to be competitive within the global economy. Amir (Pakistan, worker-Canada) wants the same global opportunities for his son:

I want to grow my son here [in Canada], so that my son can decide where he has to go for study and stuff. I just want to give the freedom to go anywhere, which I lacked of in my childhood. When I wanted to study, I didn't have those opportunities. I want to give those opportunities to my son, so he can go to the University of Alberta or Harvard or LSE, London School of Economics... so I think money anybody can have, but respect? I just want to run for the respect. 
The red passport and the freedom to move around the world includes respect, trust and acceptance globally, by others. The difference in levels of respect based on the ladder of passports/citizenships is eloquently descripted by Zygmunt Bauman in his book Globalization: The Human Consequences:

For the inhabitants of the first world - the increasingly cosmopolitan, extraterritorial world of global businessmen, global culture managers or global academics, state borders are levelled down, as they are dismantled for the world's commodities, capital and finances. For the inhabitant of the second world, the walls built of immigration controls, of residence laws and of 'clean streets' and 'zero tolerance' policies, grow taller; the moats separating them from the sites of their desire and of dreamed-of redemption grow deeper, while all bridges, at the first attempt to cross them, prove to be drawbridges. The first travel at will, get much fun from their travel (particularly if travelling first class or using private aircraft), are cajoled or bribed to travel and welcomed with smiles and open arms when they do. The second travel surreptitiously, often illegally, sometimes paying more for the crowded steerage of a stinking unseaworthy boat than others pay for businessclass gilded luxuries - and are frowned upon, and, if unlucky, arrested and promptly deported, when they arrive. (Bauman, 1998, p. 89)

In order to gain global respect, freedom, and stability, participants also shared stories of giving up their education for the chance of obtaining a stronger citizenship. In Portugal, a Nepalese student shared with me a story of one of her classmates, a woman considered too old to be in Grade 11. The woman had her birth certificate changed to read that she was 16 years old in order to be eligible to migrate to Portugal for family reunification and, therefore, obtain a red passport. At the time, she was completing her Bachelor's degree. The student emphasized how this woman struggles to pretend to be young in class. Yulianna, who migrated to Norway, also withdrew in the middle of her education to pursue the advantage of the red passport, leaving Nepal in the middle of her Bachelor's degree as well. She had the opportunity to pursue Norwegian citizenship at the time. Both of these women decided that the pursuit of the red passport has the potential to achieve a higher level of freedom than their own formal education.

Santosh, a worker in Portugal, originally from Nepal explains the freedom and strength of true global citizenship and why it is worth fighting for:

It is my view that when you get citizenship of Portugal, then we can go to other countries. Just to have a passport of Nepal, then we cannot go to other countries. So we can free to go to other place...If we want to change our nationality, then I think Norway is good, Canada is good. If I stay there, I get a passport. My life is strong.

Unfortunately, sometimes sacrificing one's education to start the quest for global mobility rights, does not end with the freedom of global mobility. Many individuals become undocumented or return home based on their contracts ending and/or immigration papers not being renewed. Jason, a worker in Canada with Philippines citizenship, was one of these workers. After 
obtaining a degree in electrical engineering in the Philippines (through financial support from his father working in Saudi Arabia), for nine years he worked in an electrical factory in Taiwan. There was no chance of obtaining a red passport in Taiwan. He then decided to pay recruiters to help him get into Canada. He applied to work as a kitchen helper, leaving behind his electrical engineering education for the hope of stability and global mobility rights while working in Canada's high-income economy for two years. At the end of his two years, Canada did not renew his temporary residency papers. He explained that at least in Taiwan there is more stability as you are not forced out of the country based on a limited number of years that you can work:

In Taiwan even though not permanent [citizenship] opportunity there, you can still work if you want to, but here [in Canada] the government wants you to go home... It's very hard for me because I am the only one supplying life to my family, but if I have no work, I don't know. If I go home, for sure I don't have work.

The major difference between countries in Asia using migrant workers compared to Canada and parts of Europe is the hope in Canada and Europe for the red passport. Workers know that systems in the United Arab Emirates, Saudi Arabia, and Taiwan do not allow citizenship for most outsiders. However, they can stay and work in these countries for many years. Every worker interviewed shared their ability to learn and advance within their companies in these countries. They expressed pride in their work, even within challenging environments. In Canada, Norway, Portugal, South Korea, and Sweden, workers were forced to begin and remain at the bottom of labour hierarchies, often working as cleaners, housekeepers or in food preparation. The hope of obtaining the red passport keeps them working in these regions, which is a major contributor to their systemic oppression.

\section{Conclusion}

The history of the world market for labour power is based on limiting the freedoms of others, for the economic benefit of the elite. Often, the workers concerned were "neither 'free' nor paid a wage" (Potts, 1990, p. 7). In the $21^{\text {st }}$ century, temporary low-paid global workers are still not free. Most of them are not free to move. Most of them are not free to find employment in their home countries. Most are not free to live with their families. The methods of importing living labour have been repackaged over time, based on system modifications to allow for higher profits: from employers having to replace slaves, to bonded labourers having to replace themselves, to low-paid global workers paying to replace each other today. Low-paid global workers pay thousands of dollars to recruiters for the "opportunity" to work in a high-income economy. Furthermore, governments and agents profit from the individual charges of each bureaucratic signature required for migration papers. Remittances sent to low-income countries from workers abroad are now being discussed as a new form of development aid (World Bank, 2015; Work Bank Group, 2015), saving high-income countries more money as aid shifts onto the backs of unfree labour in their territories.

Canada has found yet another way in which to profit off the labour of those temporary foreign workers that enter its borders: pension investments. All workers across Canada, including temporary foreign workers, contribute to the Canada Pension Plan (Canada Pension Plan, 1985). These deductions are pooled together across Canada and are invested by the Canadian Pension

Journal of Contemporary Issues in Education, 2017, 12(1), pp. 4-18.

ISSN 1718-4770 (C) 2017 University of Alberta/Centre for Global Citizenship Education and Research http:/lejournals.library.ualberta.ca/index.php/JCIE 
Plan Investment Board. Current investments include equity holdings in major global mining corporations (CPPIB, 2015). Therefore, the payments from temporary foreign workers contribute toward Canadian pensions that they may never have access to as well as investments in the very companies that share the responsibility of their displacement from their home countries.

Global belonging is at the crux of global citizenship. While passports are issued according to national citizenship, they in turn provide high or low levels of global freedom or global belonging. In the context of global labour migration, a true global citizen is someone in possession of a red passport. The experiences described in this study suggest that global citizenship, or the red passport, serves the continued prosperity of rich countries through a hierarchical system of global mobility that, at its base, is a repackaged formation of the control of others for their labour. These outside the classroom realities of global citizenship, in this case of global mobility rights, must not be ignored within the development of the educational concept of global citizenship in the classroom.

Marco, the Filipino Canadian Community Organizer, shared with me his reflection about a global citizenship protest sign he had seen once which stated: "No Borders, No Nations":

It is deeper than that. That is why the US is in my country, why Canada is mining my country. I don't want more Canadian companies in my country. I want the freedom to have work in my country and not be forced to leave. We are here [in Canada] because you are there [in the Philippines] and then you deport us back.

Borders exclude and divide as well as protect. However, the global citizenship knowledge shared from low-paid global workers traversing the globe, collectively portray the strength of some borders (or citizenships) at the expense of others.

\section{Acknowledgements}

I would like to acknowledge all those individuals who shared their stories with me as part of this study. I would also like to thank Lene Buchert for her guidance and support. I am incredibly indebted to Jenelle Pederson for her assistance with revisions. Finally, I am grateful to Madhu Sood and Tara Budha for inspiring me to begin this project. 


\section{References}

Arton Capital (2016). Global passport power rank 2016. Retrieved from: https://www.passportindex.org/byRank.php

Bauman, Z. (1998). Globalization: The human consequences. Cambridge: Polity Press.

Bebbington, A., Hinojosa, L., Bebbington, D. H., Burneo, M. L., \& Warnaars, X. (2008). Contention and ambiguity: Mining and the possibilities of development. Development and Change, 39(6), 887-914. http://dx.doi.org/10.1111/j.1467-7660.2008.00517.x

Bush, R. (2008). Scrambling to the bottom? Mining, resources \& underdevelopment. Review of African Political Economy, 35(117), 361-366. http://dx.doi.org/10.1080/03056240802410968

Canada Pension Plan, Revised Statutes of Canada 1985, c C-8, Retrieved from: http://canlii.ca/t/52hkh

Canadian Pension Plan Investment Board. (CPPIB). (2015). Our investments. Retrieved from: http://www.cppib.com/en/what-we-do/our-investments.html

Carey, B. (2016). Slavery Timeline 1400-1500. A chronology of slavery, abolition, and emancipation in the fifteenth century. Retrieved from: http://www.brycchancarey.com/slavery/chrono2.htm

Choudry, A., \& A. Smith. (Eds.). (2016). Unfree labour? Struggles of migrant and immigration workers in Canada. Oakland, California: PM Press.

Citizenship and Immigration Canada. (2016). Immigrate as a skilled worker through Express Entry. Retrieved from: http://www.cic.gc.ca/english/immigrate/skilled/index.asp

Coumans, C. (2007). A sample of Canadian mining companies operating in developing countries accused of human rights and environmental abuses. Mining Watch Canada. Retrieved from: http://miningwatch.ca/sites/default/files/problematic_canadian_mining_cases_0.pdf

Faraday, F. (2012). Made in Canada: How the law constructs migrant workers' insecurity. Toronto: Metcalf Foundation. Retrieved from: http://metcalffoundation.com/wpcontent/uploads/2012/09/Made-in-Canada-Full-Report.pdf

Fiji, Guyana, Suriname, Trinidad and Tobago. (2010). Records of the Indian Indentured Labourers. Memory of the World Register. Ref $N^{\circ}$ 2010-35. Retrieved from: http://www.unesco.org/new/fileadmin/MULTIMEDIA/HQ/CI/CI/pdf/mow/nomination_f orms/fiji_guyana_suriname_trinidad_records_indian_indentured_languages.pdf

Gordon, T., \& Webber, J. R. (2008). Imperialism and resistance: Canadian mining companies in Latin America. Third World Quarterly, 29(1), 63-87. http://dx.doi.org/10.1080/01436590701726509

Holden, W., Nadeau, K., \& Jacobson, R. D. (2011). Exemplifying accumulation by dispossession: mining and indigenous peoples in the Philippines. Geografiska Annaler: Series B, Human Geography, 93(2), 141-161. http://dx.doi.org/10.1111/j.14680467.2011.00366.x

International Labour Office (ILO). (2004). Towards a fair deal for migrant workers in the global economy. Geneva. Retrieved from: http://www.ilo.org/public/english/standards/relm/ilc/ilc92/pdf/rep-vi.pdf

Levush, R. (2013). Guest worker programs: Comparative analysis. Library of Congress. Retrieved from: https://www.loc.gov/law/help/guestworker/comparative_analysis.php

Journal of Contemporary Issues in Education, 2017, 12(1), pp. 4-18. ISSN 1718-4770 (C) 2017 University of Alberta/Centre for Global Citizenship Education and Research http:/lejournals.library.ualberta.ca/index.php/JCIE 
MDCSN (Migration and Development Civil Society Network). (2014). Open letter from Civil Society to UN Secretary-General Ban Ki-moon and President of the UN General Assembly Sam Kutesa on the occasion of International Migrants Day. Retrieved from: http://gfmd_turkey2014-2015_open-letter_unsg_unpga-civil_societystockholm_agenda\%20(1).pdf

Potts, L. (1990). The world labour market: A history of migration. London: Zed Books Ltd.

Rodriguez, R. (2010). Migrants for export: How the Philippines state brokers labor to the world. Minneapolis: University of Minnesota Press.

Ruhs, M. (2012). The human rights of migrant workers: Why do so few countries care? American Behavioral Scientist, 56(9), 1277-1293. http://dx.doi.org/10.1177/0002764212443815

Ruhs, M. (2013). The price of rights: Regulating international labor migration. Princeton: Princeton University Press.

Serviço de Estrangeiros e Fronteiras. (2012). Regime for Foreign Nationals Act 23/2007 of July 4, amended by Act 29/2012 of August 9. Retrieved from: http://www.sef.pt/documentos/56/LeideImig(Lei29_2012)EN.pdf\#1

Tawil, S. (2013). Education for 'global citizenship': A framework for discussion. UNESCO Education Research and Foresight, Paris. ERF Working Papers Series, No. 7. Retrieved from: http://unesdoc.unesco.org/images/0022/002237/223784e.pdf

World Bank. (2015). Migration and remittances: Recent developments and outlook. Special topic: Financing for development. Migration and Development Brief, 24. Retrieved from: https://siteresources.worldbank.org/INTPROSPECTS/Resources/3349341288990760745/MigrationandDevelopmentBrief24.pdf

World Bank Group. (2015). Global Economic Prospects, January 2015: Having Fiscal Space and Using It. Washington, DC: World Bank. http:dx.doi.org/10.1596/978-1-4648-0444-1 